\title{
Effect of Senna obtusifolia (L.) invasion on herbaceous vegetation and soil properties of rangelands in the western Tigray, northern Ethiopia
}

\author{
Maru G. Gebrekiros ${ }^{1}$ and Zewdu K. Tessema $2^{*}$
}

\begin{abstract}
Introduction: Invasion of exotic plant species is a well-known threat to native ecosystems since it directly affects native plant communities by altering their composition and diversity. Moreover, exotic plant species displace native species through competition, changes in ecosystem processes, or allelopathic effects. Senna obtusifolia (L.) invasion has affected the growth and productivity of herbaceous vegetation in semi-arid regions of northern Ethiopia. Here, we investigated the species composition, species diversity, aboveground biomass, and basal cover of herbaceous vegetation, as well as soil properties of rangelands along three S. obtusifolia invasion levels.

Methods: Herbaceous vegetation and soil properties were studied at two locations, Kafta Humera and Tsegede districts, in the western Tigray region of northern Ethiopia under three levels of S. obtusifolia invasion, i.e., non-invaded, lightly invaded, and heavily invaded. Herbaceous plant species composition and their abundance were assessed using a $1-m^{2}$ quadrat during the flowering stage of most herbaceous species from mid-August to September 2015. Native species were classified into different functional groups and palatability classes, which can be useful in understanding mechanisms underlying the differential responses of native plants to invasion. The percentage of basal cover for S. obtusifolia and native species and that of bare ground were estimated in each quadrat. Similar to sampling of the herbaceous species, soil samples at a depth of $0-20 \mathrm{~cm}$ were taken for analyzing soil physical and chemical properties.

Results: Highly palatable grasses and legumes based on the frequency of occurrence were 1.9 and 3.8 times higher in non-invaded sites than in lightly and heavily invaded sites, respectively. Furthermore, unpalatable plant species were 4.0 times higher in the heavily invaded sites than in the lightly invaded sites. Aboveground biomass, basal cover, and species diversity of the herbaceous vegetation were significantly $(P<0.01)$ lower in the heavily invaded sites compared to the non-invaded sites. However, most soil properties were not affected by $S$. obtusifolia invasion compared with non-invaded sites in our study.

Conclusions: Our findings contribute towards better understanding of how S. obtusifolia invasion affects the community structure and composition of native herbaceous vegetation in semi-arid rangelands in northern Ethiopia. Further long-term studies are required to understand the mechanisms of how S. obtusifolia invasion influences soil properties for better control and eradication of its invasion in the semi-arid rangelands of northern Ethiopia.
\end{abstract}

Keywords: Aboveground biomass, Basal cover, Invasion level, Palatability, Species composition, Species diversity

\footnotetext{
* Correspondence: tessemazewdu@gmail.com

${ }^{2}$ Rangeland Ecology and Biodiversity Program, School of Animal and Range

Sciences, College of Agriculture and Environmental Sciences, Haramaya

University, PO Box 138, Dire Dawa, Ethiopia

Full list of author information is available at the end of the article
} 


\section{Introduction}

Most rangelands around the world are partly dominated by "novel" or "emerging" ecosystems (Bridgewater et al. 2011). These novel ecosystems contain a combination of new plant species arising as a result of direct or indirect human interferences (Hobbs et al. 2006). According to Milton et al. (2007), novel ecosystems are generally created as a result of management-induced changes in native plant communities, which enable an opportunity for the invasion and/or the increase in the density of alien or exotic plant species. Many plant species have been introduced intentionally to rangeland ecosystems for various purposes. Certainly, intentional introduction of plant species may be useful in some circumstances, whereas these introduced species could create unexpected consequences and damage to the native plant communities. However, the likelihood of novel ecosystems introduced in various rangeland ecosystems increases as a result of globalization, land use and climate changes, and nitrogen deposition (Belnap et al. 2012).

Invasion of exotic (non-native) plant species causes a serious threat to the management and conservation of biodiversity worldwide (Grice 2006). Invasion of non-native plant species is one of the most important threats to native ecosystems (Mack et al. 2000) since it directly affects native plant communities by altering the composition and diversity (Wardle et al. 2011). Moreover, non-native plant species displace native species through competition, changes in ecosystem processes, or allelopathic effects (Levine et al. 2003) and have negative impacts on native species through reducing germination, growth, survival, and reproduction (Dorning and Cipollini 2006). Subsequently, less palatable and unpalatable as well as invasive tolerant annual species increase in population and become dominant in semi-arid rangelands (Solomon et al. 2007; Tessema et al. 2011). According to Solomon (2015), a higher-proportion composition of unpalatable forbs and a lower-proportion composition of palatable herbaceous plant species in sites heavily invaded by Senna obtusifolia (L.) may indicate the severe competitive effect of S. obtusifolia on rangeland ecosystems. This leads to the disappearance of annual and perennial grasses used as major feed resources (Zimmerman et al. 2010; Tessema et al. 2011), which is a serious challenge in arid and semi-arid rangelands (Vetter 2005; Kassahun et al. 2008; Boufennara et al. 2012). More importantly, livestock herders in the western Tigray region of Ethiopia are currently facing a decline in forage quality due to the loss of palatable species and lack of adequate forage for their livestock during dry seasons as a result of $S$. obtusifolia invasion (Teame et al. 2014; Solomon 2015).

Senna obtusifolia is commonly called as a sickle pod and is an erect and bushy annual or short-lived perennial, non-nodulating weed in the family Fabaceae (Tungate et al. 2002), growing to a height of $1.5-2.5 \mathrm{~m}$
(Holm et al. 1997). It is native to tropical South America but has become widespread throughout the tropics and subtropics (Teem et al. 1980). Senna obtusifolia is an aggressive invader of rangelands and can completely outcompete palatable grass species and eradicate the growth of pasture species, leading to the exclusion of livestock in semi-arid rangelands (Randell 1995) through reducing carrying capacities of rangelands by as much as $85 \%$ (Mackey et al. 1997). For instance, S. obtusifolia was reported as a primary weed of pastures in Australia, where it reduces available grazing areas and competes with pasture species for light, nutrients, and water (Mackey et al. 1997). In areas favorable for its growth, $S$. obtusifolia is capable of excluding all native species and forming dense mono-specific stands and consequently causing significant ecological changes (Mackey et al. 1997; Tye et al. 2003).

However, edaphic and environmental conditions could facilitate the reproductive success of $S$. obtusifolia during its life cycle, leading to its prolific and widespread nature in diverse ecosystems (Tungate et al. 2002). Moreover, disturbed environments may better facilitate $S$. obtusifolia invasion compared to undisturbed habitats (Dunlop et al. 2006; Solomon and Yayneshet 2014), suggesting that S. obtusifolia reproduction and offspring competitiveness can be strongly influenced by soil fertility (Tungate et al. 2002). Although previous studies have reported the effects of S. obtusifolia on herbaceous vegetation and soils in some parts of the world (Mackey et al. 1997; Tye et al. 2003; Dorning and Cipollini 2006; Awodoyin and Ogunyemi 2008), information on the effects of S. obtusifolia on native herbaceous vegetation and soil characteristics along an invasion gradient in semi-arid rangelands of northern Ethiopia is lacking, where transhumant pastoralism is a typical feature. Therefore, we studied the effects of S. obtusifolia invasion on herbaceous plant species composition, species diversity, basal cover, and biomass, as well as soil physical and chemical properties of rangelands in the western Tigray region of Ethiopia. In this study, we tested the following hypotheses that $S$. obtusifolia invasion (i) reduces the herbaceous plant species diversity and their plant abundance, (ii) reduces basal cover and aboveground biomass of palatable herbaceous plant species, and (iii) increases soil fertility of the rangelands.

\section{Methods}

\section{Description of the study areas}

This study was conducted in Kafta Humera and Tsegede districts in western Tigray region, northern Ethiopia (Fig. 1), $991 \mathrm{~km}$ away from Addis Ababa, the capital of Ethiopia, to the north direction (ZOIC 2015). The average annual rainfall of Kafta Humera and Tsegede were 572 and $638 \mathrm{~mm}$, respectively. The elevations of Kafta 


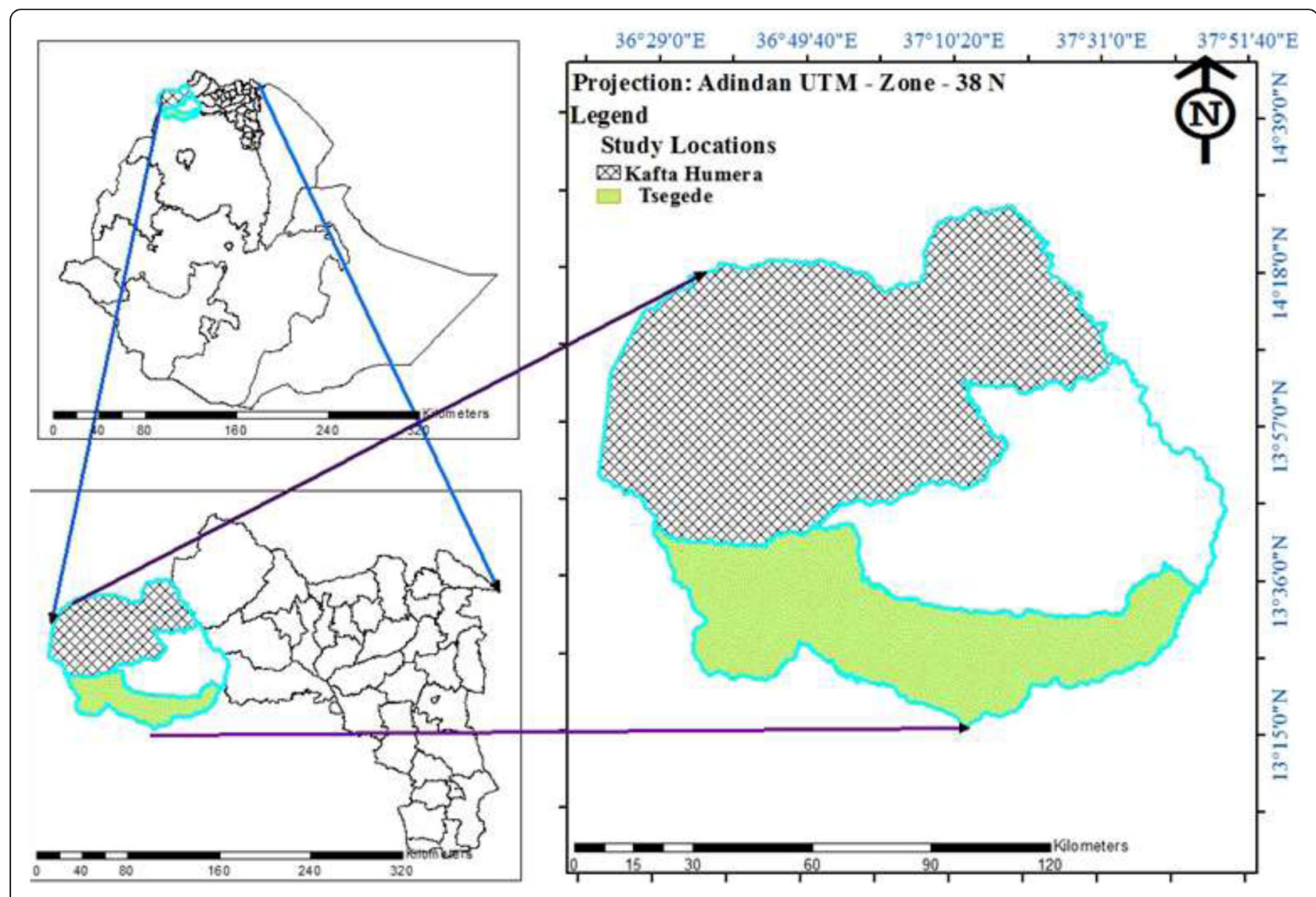

Fig. 1 Location map of the study areas, Kafta Humera and Tsegede districts in the western Tigray region, northern Ethiopia

Humera and Tsegede range from 681 to $784 \mathrm{~m}$ asl and from 726 to $806 \mathrm{~m}$ asl, respectively (ZOIC 2015). The dominant soil type in the study area is vertisol (EARO 2002).

\section{Selection of sampling plots}

Purposive sampling procedure was followed to select two locations, Kafta Humera and Tsegede districts, in the western Tigray region of northern Ethiopia, based on the levels of S. obtusifolia invasion on the rangelands. Prior to the actual site selection and field work, observation was made using reconnaissance field trips throughout the two districts to assess the general overview of the invasion and distribution of S. obtusifolia. After that, a stratified sampling procedure was employed to group the rangelands in both locations into three invasion levels: non-invaded sites with $0 \%$ species composition of S. obtusifolia, lightly invaded sites with $20-50 \%$ species composition of S. obtusifolia, and heavily invaded sites with $>50 \%$ species composition of S. obtusifolia. According to Richardson et al. (2000), greater than $50 \%$ of $S$. obtusifolia invasion on native rangelands is categorized as ecologically harmful. Finally, in each invasion level of both locations, four plots were selected using a random sampling procedure. The study was conducted during the main rainy season, from the beginning of May 2015 for plot selection until the end of October 2015 for vegetation and soil data collection.

\section{Sampling of herbaceous vegetation}

For all sampling plots, the herbaceous plant species composition and their abundance were assessed using a $1-\mathrm{m}^{2}$ quadrat during the flowering stage of most herbaceous plant species between mid-August and September 2015. Nine quadrats were taken from each site $(10 \mathrm{~m} \times 10 \mathrm{~m})$, yielding a total of 216 quadrats (two locations $\times$ three invasion levels $\times$ four plots $\times$ nine quadrats) (Fig. 2). Species composition of the herbaceous plants at each plot was determined using a quadrat count method (t'Mannetje and Jones 2000). Each herbaceous species was identified and recorded in the field. For some plant species that were difficult to identify in the field, their local names were recorded and herbarium specimens were collected, pressed and dried properly, and transported to the Herbarium at the Mekelle University of Ethiopia, for further identification.

The herbaceous species within each quadrat was classified into grasses (annual and perennial), legumes, and forbs (neither grasses nor legumes) to determine the 


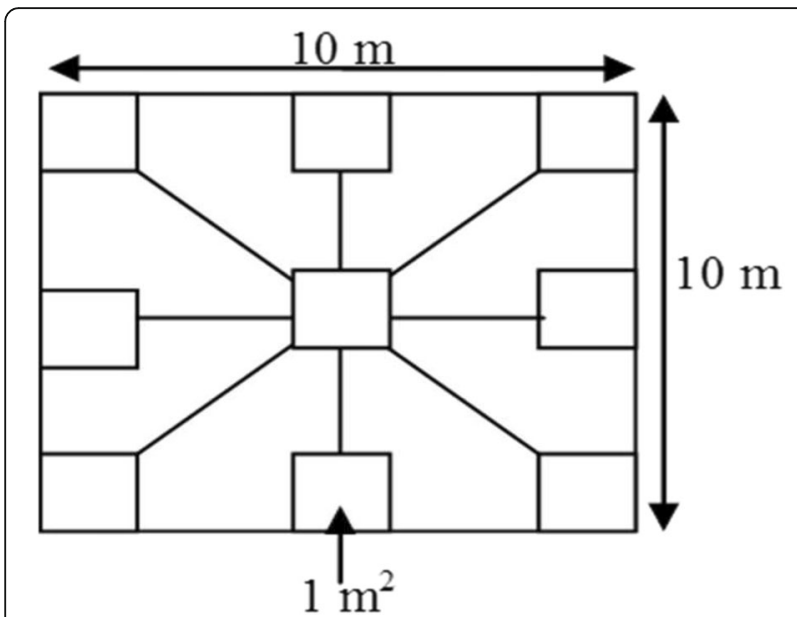

Fig. 2 Diagram illustrating quadrat position in a $10 \mathrm{~m} \times 10 \mathrm{~m}$ sampling site for recording data on species composition, species richness, basal cover, biomass yield, and soil properties under three S. obtusifolia invasion levels (non-invaded, lightly invaded, and heavily invaded) at two locations in northern Ethiopia

contribution of each group in the quadrat (ILCA 1990). Individual plants of each species were counted in each quadrat to determine its absolute abundance. Herbaceous species were categorized into four palatability classes, as highly palatable, palatable, less palatable, and unpalatable based on the opinion of livestock herders and according to Tainton (1981). The percentage of basal cover of S. obtusifolia and other herbaceous plant species and that of bare ground were estimated visually in each quadrat. The aboveground biomass of herbaceous vegetation was determined by harvesting $S$. obtusifolia and other herbaceous species at the ground level $(2 \mathrm{~cm}$ near to the ground) using a hand-operated sickle. Immediately after harvesting, the whole fresh weight of plant species within each quadrat was weighed. After that, S. obtusifolia and other herbaceous species were separated, and subsamples were obtained to determine the dry matter of each component by oven-drying at $105{ }^{\circ} \mathrm{C}$ for $24 \mathrm{~h}$ (ILCA 1990).

\section{Soil sampling and analyses}

Similar to sampling of the herbaceous layer, nine soil samples (one per $1-\mathrm{m}^{2}$ quadrat) at a depth of $0-20 \mathrm{~cm}$ were taken using a soil auger for analyzing soil physical and chemical properties, yielding a total of 216 samples (two locations $x$ three invasion levels $\times$ four plots $\times$ nine quadrats). Soil samples from the same plot were mixed together to form one composite soil sample per plot, yielding a total of 24 soil samples (two locations $\times$ three invasion levels $\times$ four plots). The soil samples were properly air-dried and grinded using a mortar and pestle to pass through a 2-mm sieve to eliminate debris and gravel. Finally, each of the 24 composite soil samples was divided into three equal parts, out of which one was used for the soil analyses. For determination of soil bulk density, one sample per sampling site in a $100-\mathrm{cm}^{3}$ soil core was taken using $50-\mathrm{mm}$-wide metallic rings hammered into the top soil and weighed its fresh weight. Before taking the core sample, 24 cans (core samplers) were weighed and labeled for each plot.

The soil samples were analyzed for texture (sand, silt, and clay proportions), soil organic matter (SOM), organic carbon (OC), pH, bulk density, electrical conductivity (EC), cation exchangeable capacity (CEC), total nitrogen (TN), available phosphorous $(\mathrm{P})$, available potassium $(\mathrm{K})$, and exchangeable bases ( $\mathrm{K}, \mathrm{Ca}, \mathrm{Mg}$, and $\mathrm{Na}$ ). The $\mathrm{pH}$ and texture of the soil were analyzed in 1:2.5 soil-to-water ratio suspensions using the Bouyoucos hydrometer method (Bouyoucos 1962). Electrical conductivity was determined using the sodium saturation ratio (Van Reeuwijk 1992). Soil OC concentration was determined according to the Walkley and Black (1934) method, and soil OM concentration was calculated by multiplying the $\mathrm{OC}$ concentration by a factor of 1.724 (Brady 1990). The concentration of TN was determined using the Kjeldahl method (Jackson 1970). Available $\mathrm{P}$ and exchangeable $\mathrm{K}, \mathrm{Ca}$, and $\mathrm{Na}$ were analyzed according to Olsen et al. (1954). CEC was analyzed using an ammonium acetate method (Van Reeuwijk 1992).

\section{Data analyses}

Herbaceous species diversity was computed using the Shannon diversity index $(H)$ according to Krebs (1999). The number of species (species richness) of the herbaceous vegetation was determined by counting all species within the $\left(1-\mathrm{m}^{2}\right)$ quadrat. Species evenness $(E)$ was derived from the ratio of the observed diversity $(H)$ to the maximum possible value of $H$ (if every species was equally likely, $\left.H_{\max }\right)$. The similarity of plant species between invasion level and location was analyzed using the Jaccard similarity index (Maguran 2004). Herbaceous species richness, evenness, species diversity, and similarity indices were calculated using PAST (Paleontological Statistics) software, version 3.04 (Hammer et al. 2001). To test for differences in all data recorded, a generalized linear model (GLM) was applied with location, invasion level, and their interactions, as independent factors, and sampling plots, as a random factor, using SAS software (SAS 2002). The Tukey HSD test was employed to investigate a significant difference between means at $P \leq 0.05$. Proportional data were arcsine transformed to meet the assumptions of normality and homogeneity of variance. The biomass of S. obtusifolia and other herbaceous species was computed separately and was reported in tons per hectare on a dry mass basis $\left(\mathrm{t} \mathrm{ha}^{-1}\right)$. 


\section{Results}

Herbaceous plant species composition, palatability, and functional groups

There were a total of 23 identified herbaceous plant species with the number of grasses, legumes, and forbs being 7 (30.4\%), 6 (26.1\%), and 10 (43.5\%), respectively (Table 1). Among the identified herbaceous species, Brachiaria lata was the common highly palatable annual grass in both locations. Annual species were dominant in all invasion levels (Table 1 ). The proportions of highly palatable and palatable herbaceous species were significantly $(P<0.05)$ higher in the non-invaded sites in both locations, while that of un-palatable herbaceous plant species was significantly $(P<0.05)$ higher in the heavily invaded sites of both locations (Fig. 3). The proportion of less palatable herbaceous species was lower in the heavily invaded and non-invaded sites at Kafta Humera and Tsegede, respectively (Fig. 3). Similarly, the proportion of grass and legume species was significantly $(P<0.05)$ higher in the non-invaded sites than in the lightly and heavily invaded sites in both locations (Fig. 4).

\section{Biomass and basal and bare ground covers}

Invasion level had a significant $(P<0.01)$ effect on the aboveground biomass and basal cover of herbaceous species and on the bare ground cover in both locations (Figs. 5 and 6). The non-invaded sites had a higher aboveground biomass and basal cover of other herbaceous species than the heavily invaded sites (Figs. 5 and 6). In contrast, the biomass and basal cover of S. obtusifolia were significantly $(P<0.01)$ higher in the heavily invaded sites compared to those in the non-invaded and lightly invaded sites (Table 2). The interaction between invasion level and location had a significant $(P<0.01)$ effect on the biomass of $S$. obtusifolia. However, the percentages of biomass and basal and bare ground covers of other herbaceous species

Table 1 List of herbaceous species with their absolute abundance (number of plants in $\mathrm{m}^{-2}$ ), life forms (LF), functional groups (FG), and palatability category (PC) under three invasion levels of Senna obtusifolia (L.) (NI non-invaded; LI lightly invaded, HI heavily invaded) at two locations, northern Ethiopia

\begin{tabular}{|c|c|c|c|c|c|c|c|c|c|}
\hline \multirow[t]{3}{*}{ Species name } & \multicolumn{6}{|c|}{ Location } & \multirow[t]{3}{*}{ LF } & \multirow[t]{3}{*}{ FG } & \multirow[t]{3}{*}{ PC } \\
\hline & \multicolumn{3}{|c|}{ Kafta Humera } & \multicolumn{3}{|c|}{ Tsegede } & & & \\
\hline & $\mathrm{HI}$ & $\mathrm{LI}$ & $\mathrm{NI}$ & $\mathrm{HI}$ & $\mathrm{LI}$ & $\mathrm{Nl}$ & & & \\
\hline Acanthospermum hispidum & 2.70 & 0.00 & 0.00 & 2.69 & 0.00 & 0.00 & A & $\mathrm{F}$ & $\overline{U P}$ \\
\hline Alysicarpus rugosus & 1.83 & 5.30 & 5.93 & 9.88 & 2.91 & 4.50 & A & L & $L P$ \\
\hline Bidens pilosa & 2.00 & 4.00 & 0.00 & 1.11 & 4.00 & 0.00 & A & $\mathrm{F}$ & $L P$ \\
\hline Brachiaria lata & 14.54 & 10.96 & 9.77 & 17.37 & 14.00 & 14.84 & $A$ & G & $\mathrm{HP}$ \\
\hline Commelina latifolia & 3.40 & 3.60 & 0.00 & 3.45 & 3.75 & 0.00 & A & $\mathrm{F}$ & LP \\
\hline Commelina diffusa & 0.00 & 3.20 & 4.00 & 1.00 & 1.60 & 2.50 & A & $\mathrm{F}$ & $L P$ \\
\hline Corchorus olitorius & 2.00 & 4.25 & 2.88 & 2.30 & 4.00 & 2.33 & A & $\mathrm{F}$ & $P L$ \\
\hline Corchorus trilocularis & 0.00 & 1.67 & 0.00 & 0.00 & 0.00 & 2.00 & A & $F$ & $L P$ \\
\hline Cyperus rotundus & 0.00 & 2.00 & 4.83 & 2.00 & 2.00 & 0.00 & B & $\mathrm{F}$ & LP \\
\hline Digitaria ternate & 0.00 & 4.20 & 6.40 & 2.00 & 2.00 & 2.44 & A & G & $P L$ \\
\hline Echinochloa sp. & 0.00 & 1.67 & 5.58 & 0.00 & 1.00 & 4.86 & A & G & $\mathrm{HP}$ \\
\hline Hibiscus esculentus & 0.00 & 1.71 & 1.43 & 0.00 & 2.55 & 2.75 & $P$ & $F$ & $P L$ \\
\hline Indigofera sp. & 4.00 & 0.00 & 3.33 & 0.00 & 0.00 & 3.00 & A & L & $L P$ \\
\hline Ipomoea purpurea & 1.00 & 2.60 & 3.77 & 1.60 & 2.63 & 4.00 & A & $F$ & $\mathrm{HP}$ \\
\hline Pennisetum glabrum & 2.00 & 0.00 & 15.60 & 1.00 & 0.00 & 4.00 & A & G & $L P$ \\
\hline Pennisetum pedicellatum & 4.00 & 8.27 & 11.96 & 0.00 & 2.33 & 10.13 & A & G & $P L$ \\
\hline Rhynchosia malacophylla & 0.00 & 4.25 & 11.00 & 1.00 & 4.27 & 20.58 & A & L & $\mathrm{HP}$ \\
\hline Rhynchosia minima & 0.00 & 1.89 & 2.50 & 0.00 & 0.00 & 3.07 & A & $\mathrm{L}$ & $\mathrm{HP}$ \\
\hline Rottboellia cochinchinensis & 0.00 & 2.56 & 2.37 & 0.00 & 3.07 & 2.78 & A & G & $\mathrm{HP}$ \\
\hline Sorghum aethiopicum & 0.00 & 1.33 & 3.06 & 0.00 & 2.60 & 3.56 & A & G & $\mathrm{PL}$ \\
\hline Striga hermonthica & 2.43 & 0.00 & 0.00 & 1.78 & 0.00 & 0.00 & A & $\mathrm{F}$ & UP \\
\hline Xanthium abyssinicum & 2.00 & 2.09 & 0.00 & 2.29 & 2.11 & 0.00 & A & $\mathrm{F}$ & UP \\
\hline Zehneria scabra & 0.00 & 1.63 & 1.30 & 1.00 & 1.33 & 1.33 & A & $\mathrm{F}$ & $\mathrm{PL}$ \\
\hline
\end{tabular}




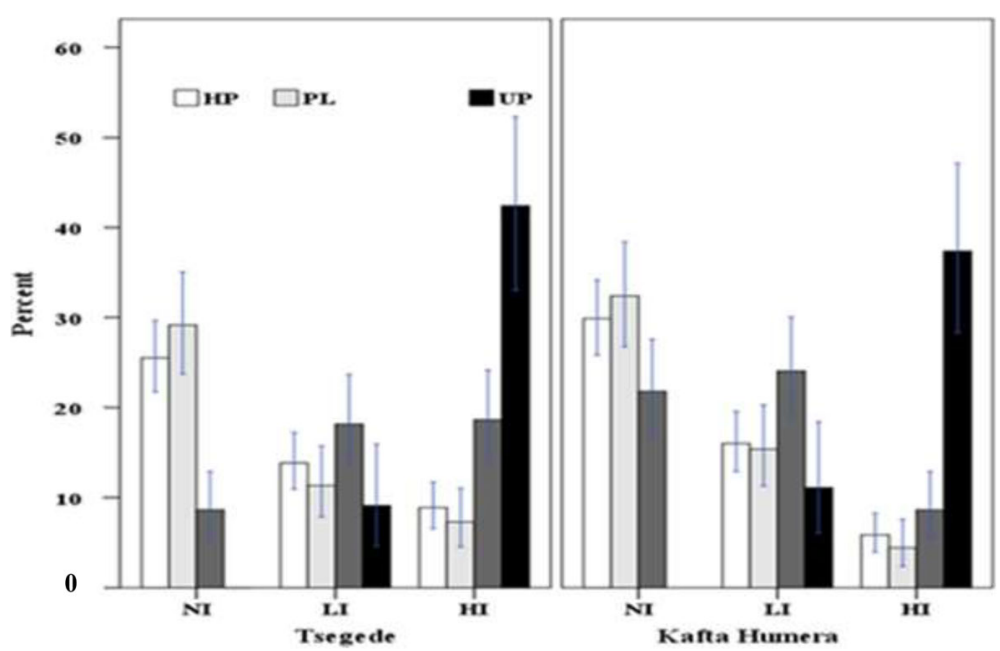

Fig. 3 Percentage of palatability of herbaceous vegetation (based on the frequency of occurrence; HP highly palatable, PL palatable, LP less palatable, UP unpalatable) under three Senna obtusifolia invasion levels (NI non-invaded, LI lightly invaded, HI heavily invaded) at Kafta Humera and Tsegede districts in northern Ethiopia. Bars indicate the SE of the mean

were not influenced $(P>0.05)$ by the interaction of invasion level with location (Table 2).

\section{Herbaceous plant species diversity and similarity}

Species evenness, Shannon diversity index, species richness, and dominance of other herbaceous plant species varied significantly $(P<0.05)$ along invasion levels (Tables 2,3 , and 4$)$. The lowest herbaceous species richness was recorded in the heavily invaded sites in both locations. The Shannon diversity index of herbaceous species was also significantly $(P<0.05)$ higher in the non-invaded and lightly invaded sites at Kafta Humera with values of 2.428 and 2.281, respectively, whereas the lowest Shannon diversity index of herbaceous species was recorded in the heavily invaded sites of Kafta Humera and Tsegede, with values of 1.237 and 1.509 , respectively (Table 3 ).

The herbaceous plant species was evenly $(P<0.05)$ distributed in the non-invaded (0.667) and lightly invaded (0.5149) sites in Kafta Humera than in the non-invaded (0.4594) and lightly invaded (0.3737) sites in Tsegede. The poor herbaceous plant species distribution was recorded in the heavily invaded sites in both locations (Table 3). The dominance of few herbaceous plant species was recorded in the heavily invaded sites of Kafta Humera (0.5005) compared with those of Tsegede (0.3594) (Table 3). A higher Jaccard coefficient of similarity of the herbaceous plant species was recorded in the non-invaded and lightly invaded sites within and

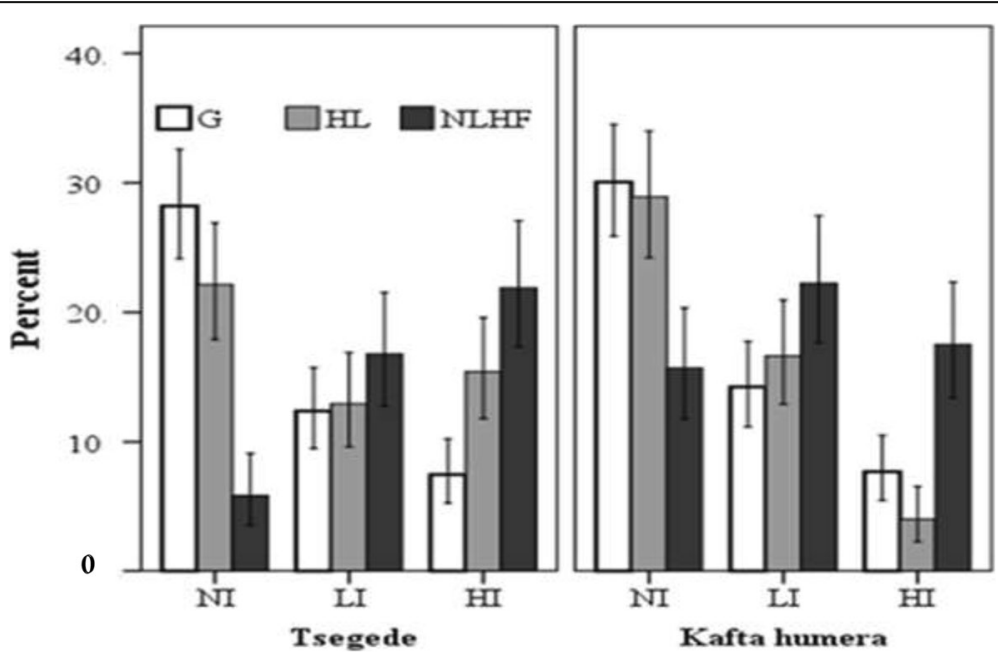

Fig. 4 Percentage of functional groups based on the frequency of occurrence (G grass species, HL herbaceous legumes, NLHF neither grasses nor legumes) of the herbaceous vegetation under three S. obtusifolia invasion levels (NI non-invaded, LI lightly invaded, HI heavily invaded) at two locations in northern Ethiopia. Bars indicate the SE of the mean 


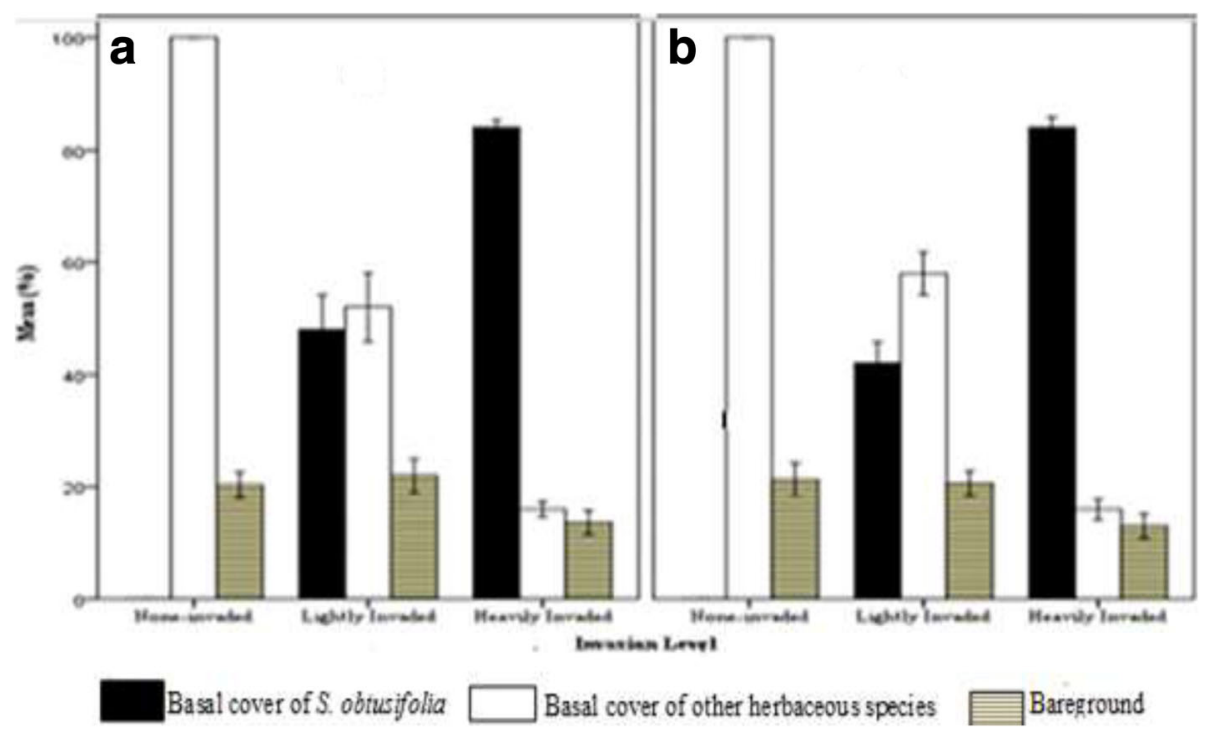

Fig. 5 Percentage of bare ground, basal cover of S. obtusifolia, and basal cover of other herbaceous species under three invasion levels (non-invaded, lightly invaded, and heavily invaded) at Kafta Humera (a) and Tsegede (b) district in the western Tigray region, northern Ethiopia

between locations, whereas higher species dissimilarity values were recorded between the heavily invaded and non-invaded sites in both locations (Table 4).

\section{Soil properties}

Clay was the dominant fraction of the soil in all invasion levels and both locations. Similarly, the content of silt did not vary in both locations and invasion levels. However, the percentage of sand content of Kafta Humera was higher than that of Tsegede. The lightly invaded sites in both locations had a higher sand content than the heavily invaded and non-invaded sites. The sand content was not affected $(P>0.05)$ by the interaction of location with invasion level (Table 5).

The $\mathrm{pH}$ did not vary significantly $(P>0.05)$ between the invasion levels. Neither invasion level nor location had a significant $(P>0.05)$ effect on the TN (\%) of the study regions (Table 5). The value of $\mathrm{EC}$ was significantly $(P<0.01)$ different between the two study locations, as Tsegede had relatively higher EC values than did Kafta Humera. The value of EC was higher in the lightly invaded and heavily invaded sites in both

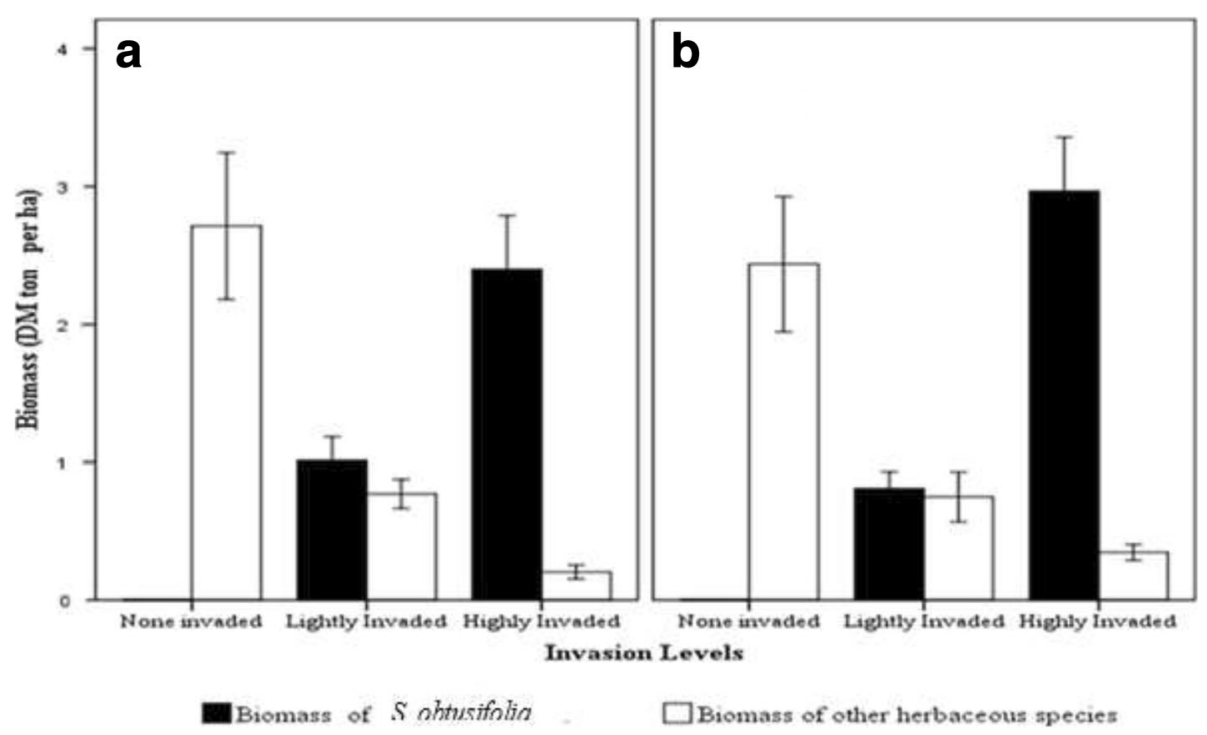

Fig. 6 Biomass yield of S. obtusifolia and other herbaceous vegetation (DM t ha ${ }^{-1}$ ) under three invasion levels (non-invaded, lightly invaded, and heavily invaded) at Kafta Humera (a) and Tsegede districts (b) in the western Tigray region, northern Ethiopia. Bars indicate the SE of the mean 
Table 2 Species richness (number of species $\mathrm{m}^{-2}$ ) and absolute abundance (numbers in $\mathrm{m}^{-2}$ ) of herbaceous vegetation and bare ground (\%) under three invasion levels of Senna obtusifolia (L.) (non-invaded, lightly invaded, and heavily invaded) at two locations in northern Ethiopia, with statistical results of the GLM $\left(F, P, R^{2}\right.$ values $)$

\begin{tabular}{|c|c|c|c|}
\hline & $\begin{array}{l}\text { Species richness } \\
\text { of other } \\
\text { herbaceous } \\
\text { species }\end{array}$ & $\begin{array}{l}\text { Abundance } \\
\text { of other } \\
\text { herbaceous } \\
\text { species }\end{array}$ & $\begin{array}{l}\text { Abundance of } \\
\text { S. obtusifolia }\end{array}$ \\
\hline & \multicolumn{3}{|l|}{ Mean \pm SE } \\
\hline \multicolumn{4}{|l|}{ Kafta Humera } \\
\hline Non-invaded & $9.9 \pm 2.1^{\mathrm{a}}$ & $65.9 \pm 1.0^{\mathrm{a}}$ & $0.0 \pm 0.3^{c}$ \\
\hline Lightly invaded & $6.5 \pm 1.5^{b}$ & $29.7 \pm 1.8^{b}$ & $8.2 \pm 0.9^{b}$ \\
\hline Heavily invaded & $3.5 \pm 1.6^{c}$ & $20.1 \pm 1.5^{b}$ & $16.7 \pm 1.3^{\mathrm{a}}$ \\
\hline \multicolumn{4}{|l|}{ Tsegede } \\
\hline Non-invaded & $7.7 \pm 1.8^{\mathrm{a}}$ & $57.1 \pm 0.8^{\mathrm{a}}$ & $0.0 \pm 0.2^{c}$ \\
\hline Lightly invaded & $5.2 \pm 2.0^{b}$ & $25.3 \pm 2.2^{b}$ & $6.1 \pm 1.3^{b}$ \\
\hline Heavily invaded & $5.1 \pm 2.4^{c}$ & $31.2 \pm 1.6^{b}$ & $22.4 \pm 1.5^{\mathrm{a}}$ \\
\hline \multicolumn{4}{|l|}{ Location (LOC) } \\
\hline$F(d f=1156)$ & 3.89 & 0.09 & 1.38 \\
\hline P & 0.050 & 0.770 & 0.243 \\
\hline \multicolumn{4}{|l|}{ Invasion level (IL) } \\
\hline$F(d f=2156)$ & 75.28 & 1378.67 & 65.85 \\
\hline$P$ & $<0.0001$ & $<0.0001$ & $<0.0001$ \\
\hline \multicolumn{4}{|l|}{$\mathrm{LOC} \times \mathrm{IL}$} \\
\hline$F(d f=2156)$ & 13.54 & 6.75 & 6.51 \\
\hline$P$ & $<0.0001$ & 0.0015 & 0.012 \\
\hline$R_{\text {adjusted values }}^{2}$ & 0.538 & 0.581 & 0.415 \\
\hline
\end{tabular}

locations $(P<0.01$; Table 1$)$. The concentrations of soil OC, OM, exchangeable $\mathrm{K}^{+}$and $\mathrm{Na}^{+}$, and available $\mathrm{P}$ were not significantly $(P>0.05)$ affected by location, invasion level, and their interaction (Table 5). However, exchangeable cation $\mathrm{Mg}^{2+}$ showed significant $(P<0.05)$ variations between invasion levels, whereas available $\mathrm{K}$, CEC, and soil $\mathrm{pH}(P<0.05)$ were significantly affected by location only. Exchangeable $\mathrm{Ca}^{2+}$ was significantly affected by location and its interaction with invasion level $(P<0.05$; Table 5$)$.

\section{Discussion}

Effect of S. obtusifolia (L.) invasion on herbaceous species composition and diversity

In our study, the percentages of highly palatable and palatable herbaceous species were higher in the noninvaded sites compared to those in the lightly and heavily invaded sites in both locations. Furthermore, the percentage of unpalatable herbaceous plant species was higher in the heavily invaded sites than in the noninvaded and lightly sites in both locations. On the contrary, the lightly invaded sites had a higher percentage of less palatable herbaceous plant species than did the noninvaded and heavily invaded sites in both locations. Similarly, Solomon (2015) reported high distribution of unpalatable forbs in sites heavily invaded by $S$. obtusifolia. In addition, the number of species and their absolute abundance of other herbaceous plant species showed a decreasing trend from the non-invaded to the lightly and heavily invaded sites in both locations.

The percentages of grasses and legumes which are important feed resources to livestock in the study sites showed decreasing trends from the non-invaded sites to the lightly and heavily invaded sites, indicating the abundance of less palatable and unpalatable forbs since annual forbs are shade tolerant under the canopy of invasive species and propagated by seed production compared to perennial grasses, which are mainly dependent upon vegetative propagation. According to previous studies (Solomon et al. 2006; Tessema et al. 2012), the seed production potential of annual forbs is high in semi-arid rangelands due to their strong adaptation and survival strategies (Veenendaal et al. 1996), and this might lead to the availability of persistent seeds of annual forbs in the soil for further generation (Tessema et al. 2012). The higher proportion of palatable species in the non-invaded sites and their lower proportion in the heavily invaded sites might indicate the severe competitive effect of $S$. obtusifolia. This finding was similar to the results of

Table 3 Effects of Senna obtusifolia (L.) on species evenness (E), Shannon diversity index (H), and dominance $(D)$ under three invasion levels (non-invaded, lightly invaded, and heavily invaded) at two locations in northern Ethiopia

\begin{tabular}{|c|c|c|c|c|}
\hline \multirow[t]{2}{*}{ Location } & \multirow[t]{2}{*}{ Invasion level } & \multicolumn{3}{|c|}{ Diversity indices } \\
\hline & & Dominance & Shannon diversity index & Species evenness \\
\hline \multirow[t]{3}{*}{ Kafta Humera } & Heavily invaded & 0.5005 & 1.237 & 0.2870 \\
\hline & Lightly invaded & 0.1747 & 2.281 & 0.5149 \\
\hline & Non-invaded & 0.1118 & 2.428 & 0.6671 \\
\hline \multirow[t]{3}{*}{ Tsegede } & Heavily invaded & 0.3594 & 1.509 & 0.3014 \\
\hline & Lightly invaded & 0.3055 & 1.849 & 0.3737 \\
\hline & Non-invaded & 0.1894 & 2.055 & 0.4594 \\
\hline
\end{tabular}


Table 4 Jaccard coefficient of similarity for herbaceous species under three Senna obtusifolia invasion levels (non-invaded; lightly invaded, and heavily invaded) at two locations in northern Ethiopia

\begin{tabular}{|c|c|c|c|c|c|c|c|}
\hline \multirow[t]{2}{*}{ Location } & \multirow[t]{2}{*}{ Invasion level } & \multicolumn{3}{|l|}{ Kafta Humera } & \multicolumn{3}{|l|}{ Tsegede } \\
\hline & & Heavily invaded & Lightly invaded & Non-invaded & Heavily invaded & Lightly invaded & Non-invadec \\
\hline \multirow[t]{3}{*}{ Kafta Humera } & Heavily invaded & - & & & & & \\
\hline & Lightly invaded & 0.35 & - & & & & \\
\hline & Non-invaded & 0.32 & 0.71 & - & & & \\
\hline \multirow[t]{3}{*}{ Tsegede } & Heavily invaded & 0.59 & 0.55 & 0.45 & - & & \\
\hline & lightly invaded & 0.38 & 0.89 & 0.70 & 0.60 & - & \\
\hline & Non-invaded & 0.32 & 0.71 & 0.89 & 0.39 & 0.62 & - \\
\hline
\end{tabular}

Solomon (2015) and Gebrehaweria (2011), who reported the dominant nature of $S$. obtusifolia in semi-arid rangelands. According to previous studies (Dorning and Cipollini 2006; Awodoyin and Ogunyemi 2008), S. obtusifolia germinates early in the beginning of wet season and matures early in the mid-wet season, leading to take an advantage to compete for light, moisture, essential nutrients, and open space over other herbaceous species and consequently suppress the growth of other native herbaceous species.

The lower species diversity, lower than the limit of $<1.0$ according to Cavalcanti and Larrazabal (2004) in the highly invaded sites, might be caused by a higher competition effect of $S$. obtusifolia over native herbaceous species. Herbaceous plant species distribution or evenness decreased across invasion levels with the most uneven recorded in the heavily invaded sites in the present study, as a result of the dominant effect of the invading species. Generally, the lowest proportion of herbaceous species richness, Shannon diversity index, evenness, and individuals was recorded in the heavily invaded sites in both locations. This was in agreement with previous studies in various parts of the world (Rejmanek 1995; Weber 2003; Gebrehaweria 2011). Moreover, the highest Jaccard similarity index values of the species composition were recorded in the non-invaded and lightly invaded sites, indicating that S. obtusifolia invasion could affect the composition and structure of herbaceous plant communities.

\section{Effect of S. obtusifolia (L.) invasion on herbaceous biomass and basal and bare ground covers}

The percentage of basal and bare ground covers, as well as biomass of other herbaceous species, had a decreasing trend from the non-invaded sites to the lightly and heavily invaded sites in the present study. According to Dorning and Cipollini (2006) and Awodoyin and Ogunyemi (2008), the reduction in biomass and basal cover of other herbaceous plant species in the heavily invaded sites might be associated with the early germination and maturation of S. obtusifolia that might take advantage of forming a closed canopy and basal cover over native herbaceous plant species. However, the basal cover and biomass of $S$. obtusifolia showed an increasing trend from the non-invaded sites to the lightly and heavily invaded sites, which might also reduce the biomass and productivity of other native herbaceous species according to Lesoli et al. (2013) due to the competitive effect of S. obtusifolia for soil nutrients (Rejmanek 1995; Weber 2003).

\section{Effect of S. obtusifolia (L.) invasion on soil properties}

Our findings showed that S. obtusifolia at different invasion levels had no effect on most of the soil properties in both locations, which is in consistence with the findings of Awodoyin and Ogunyemi (2008). According to Parsons and Cuthbertson (2000), even though $S$. obtusifolia is a leguminous plant, it had no effect on most of the soil nutrients, because it is a non-nodulating legume, which does not have nitrogenfixing bacteria associated with its root systems (Waterhouse and Norris 1987; Weber 2003).

\section{Conclusions}

This study demonstrated that $S$. obtusifolia affected the composition of native herbaceous vegetation through replacing the proportion of palatable native species with unpalatable ones. Moreover, its invasion reduced the biomass and basal cover of native herbaceous vegetation. However, S. obtusifolia invasion did not affect most of the soil physical and chemical properties. This study, therefore, demonstrated that $S$. obtusifolia invasion in a unique north western Ethiopian rangelands utilized by a seasonal transhumant way has resulted in negative effects on herbaceous vegetation properties. The present findings contribute towards a better understanding of the mechanisms of how $S$. obtusifolia invasion changes the native herbaceous vegetation in ecologically important transhumance types of rangelands in the northern parts of Ethiopia. However, long-term studies are required to understand the mechanisms of how S. obtusifolia invasion affects soil properties for better control and eradication of its invasion in semi-arid rangelands. 


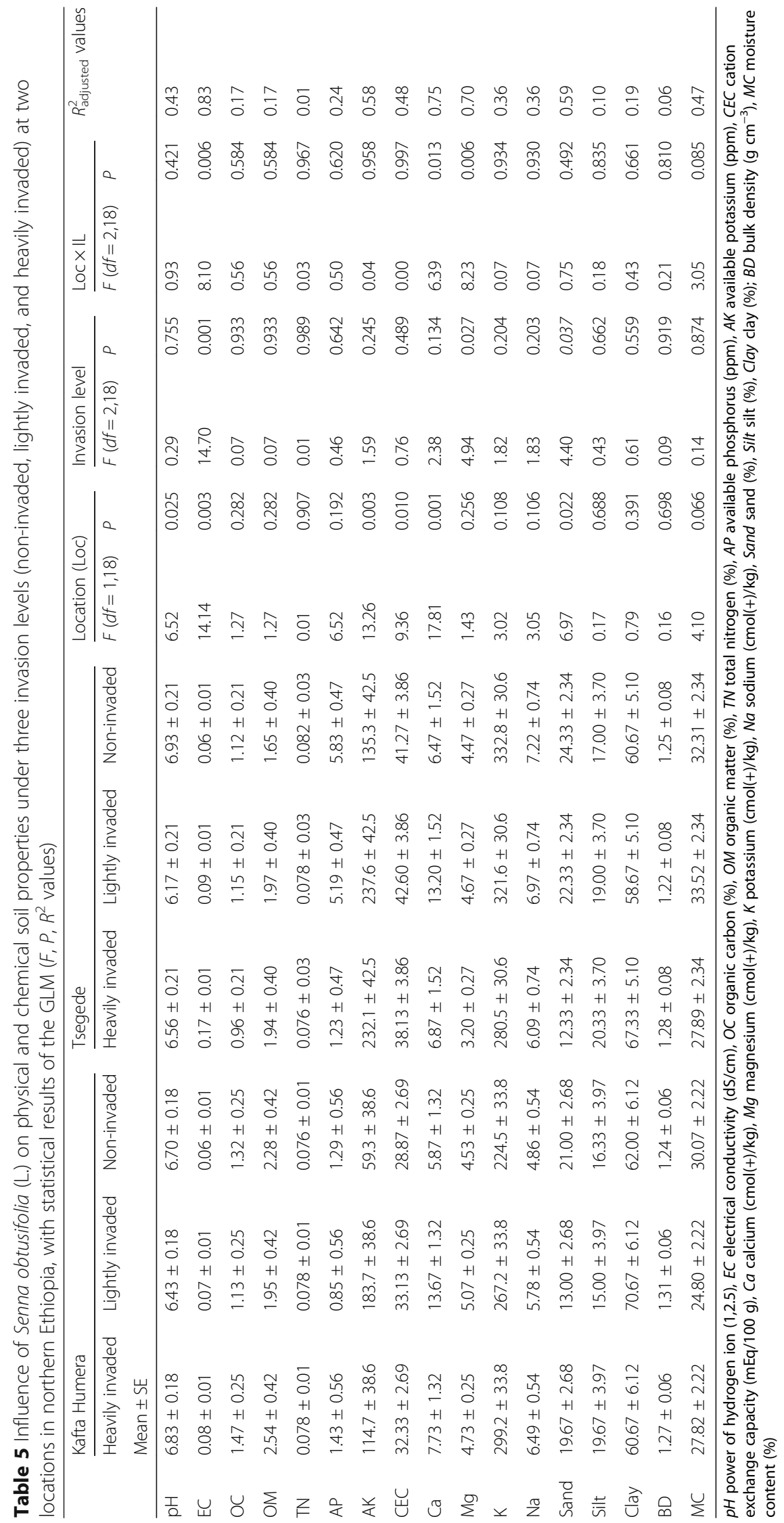




\section{Acknowledgements}

We would like to express our deepest respect to the staff members of the Humera Agricultural Research Center for their assistance during the data collection.

\section{Funding}

This research was conducted with the financial support of the Tigray Agricultural Research Institute and Humera Agricultural Research Center, northern Ethiopia.

\section{Authors' contributions}

GKM initiated the idea, collected the data, analyzed the data, and drafted the manuscript. TZK initiated the idea, interpreted the results, and critically reviewed the draft manuscript. All authors revised the manuscript and read and approved the final version.

\section{Competing interests}

The authors declare that they have no competing interests.

\section{Publisher's Note}

Springer Nature remains neutral with regard to jurisdictional claims in published maps and institutional affiliations.

\section{Author details}

'Humera Agricultural Research Center, Tigray Agricultural Research Institute, PO Box 492, Mekelle, Tigray, Ethiopia. ${ }^{2}$ Rangeland Ecology and Biodiversity Program, School of Animal and Range Sciences, College of Agriculture and Environmental Sciences, Haramaya University, PO Box 138, Dire Dawa, Ethiopia.

\section{Received: 24 September 2017 Accepted: 14 February 2018} Published online: 07 March 2018

\section{References}

Awodoyin RO, Ogunyemi S (2008) Competitive ability of sickle pod (Senna obtusifolia L.) in combination with Chromolaena odorata (L.) K. \& R. and Euphorbia heterophylla L. Trop Agri Res Ext 11:25-30

Belnap J, Ludwig JA, Wilcox BP, Betancourt JL, Dean WR, Hoffmann BD, Milton SJ (2012) Introduced and invasive species in novel rangeland ecosystems: friends or foes? Rangeland Ecol Manage 65:569-578

Boufennara S, Lopez S, Bousseboua H, Bodas R, Bouazza L (2012) Chemical composition and digestibility of some browse plant species collected from Algerian arid rangelands. Spanish J Agri Res 10:88-98

Bouyuocos GJ (1962) Hydrometer method improved for making particle size analysis of soils. American Soc Agro J 54:4644

Brady NC (1990) The nature and properties of soils, 10th edn. Macmillan Company, New York, pp 243-246

Bridgewater P, Higgs ES, Hobbs RJ, Jackson SJ (2011) Engaging with novel ecosystems. Frontiers in Ecol Environ 9:423-423

Cavalcanti EAH, Larrazábal MELD (2004) Macrozooplâncton da Zona Econômica Exclusiva do Nordeste do Brasil (segunda expediçãooceanográfica-REVIZEE/ NE II) com ênfaseem Copepoda (Crustacea). Revista Bras de Zool 21:467-475

Dorning M, Cipollini D (2006) Leaf and root extracts of the invasive shrub, Lonicera maackii inhibit seed germination of three herbs with no autotoxic effects. Plant Ecol 184:287-296

Dunlop EA, Wilson JC, Markey AP (2006) The potential of geographic distribution of the invasive weed Senna obtusifolia in Australia. Weed Res 46:404-413

Ethiopian Agricultural and Research Organization (EARO) 2002. An assessment of the agricultural production base, technological packages and innovation and intervention strategies for commercial farmers in Kafta-Humera Woreda of Tigray Regional State, Addis Ababa

Gebrehaweria K (2011) Pastoralist's perception, vegetation, diversity and condition assessment in rangelands of Kafta Humera Woreda, Tigray Regional State, Ethiopia, MSc thesis. Haramaya University, Haramaya

Grice AC (2006) The impacts of invasive plant species on the biodiversity of Australian rangelands. Rangel J 28:27-35

Hammer $\varnothing$, Harper DAT, Ryan PD (2001) PAST: Paleontological Statistics software package for education and data analysis. Palaeo Elect 4:1-9

Hobbs RJ, Arico S, Aronson J, Baron JS, Bridgewater P, Cramer VA, Epstein PR, Ewel JJ, Klink CA, Lugo AE, Norton D, Ojima D, Richardson DM, Sanderson EW, Valladares F, Vila M, Zamora R, Zobel M (2006) Novel ecosystems: theoretical and management aspects of the new ecological world order. Global Ecol Biogeo 15:1-7

Holm L, Doll J, Holm E, Pancho J, Herberger J (1997) World weeds. natural histories and distribution. Wiley, New York

ILCA (International Livestock Center for Africa) (1990) Livestock systems research manual. Working paper 1, Vol. 1. ILCA, Addis Ababa, p 287

Jackson ML (1970) Soil chemical analysis. Prenstice Hall, Inc, Engle Wood Cliffs, New Jersey

Kassahun A, Snyman HA, Smit GN (2008) Impact of rangeland degradation on the pastoral systems, livelihoods and perceptions of the Somali in eastern Ethiopia. J Arid Environ 72:1265-1281

Krebs C (1999) Similarity coefficients and cluster analysis. In: Ecological methodology, 2nd edn. Addison Wesley Longman, Inc, Menlo Park, pp 375-393

Lesoli MS, Gxasheka M, Solomon T, Moyo B (2013) Integrated plant invasion and bush encroachment management on Southern African rangelands. In: Price AJ, Kelton JA (eds) Herbicides: current research and case studies in use, pp 260-313 https://doi.org/10.5772/56182

Levine JM, Vila M, Antonio CM, Dukes JS, Grigulis K, Lavorel S (2003) Mechanisms underlying the impacts of exotic plant invasions. Biol Sci 270:775-781

Mack RN, Simberloff D, Lonsdale WM, Evans H, Clout M, Bazzaz FA (2000) Biotic invasions: causes, epidemiology, global consequences, and control. Ecol Appl 10:689-710

Mackey PA, Miller EN, Palmer WA (1997) Sicklepod (Senna obtusifolia) in Queensland-pest status review series land protection. Department of Natural Resources, Queensland Retrieved on February 29/2015 from file/0011/63875/IPA-Sicklepod-PSA.pdf

Magurran AE (2004) Measuring biological diversity. Blackwell, London, p 256

Milton SJ, Wilson JRU, Richardson DM, Seymour CL, Dean WRJ, Iponga DM, Proches S (2007) Invasive alien plants infiltrate bird-mediated shrub nucleation processes in arid savanna. J Ecol 95:648-661

Olsen SR, Cole CV, Watanable FS, Dean LA (1954) Estimation of available phosphorus in soil by extraction with sodium bicarbonate. USDA, Circ 939

Parsons WT, Cuthbertson EG (2000) Noxious weeds of Australia. Inkata, Melbourne, p 692

Randell BR (1995) Taxonomy and evolution of Senna obtusifolia and S. tora. J Adelaide Bot Gard 16:55-58

Rejmanek M (1995) What makes a species invasive? In: Pysek P, Prach K, Rejmanek M, Wade M (eds) Plant invasions general aspects and special problems. SPB Academic, Amsterdam, pp 3-13

Richardson DM, Pysek P, Rejmanek M, Barbour MG, Panetta FD, West CJ (2000) Naturalization and invasion of alien plants: concepts and definitions. Diver Distr 6:93-107

SAS (Statistical Analysis System). (2002) Version 9.0 [computer program]. SAS Institute, Cary

Solomon G (2015) Community perception on rangeland degradation: a case study in two differently settled areas of northern Ethiopia. J Agri Res Devel 5:101-107

Solomon G, Yayneshet T (2014) Rangeland vegetation responses to settlement in the semi-arid rangelands of northern Ethiopia. Scholarly J Agri Sci 4:587-595

Solomon T, Snyman HA, Smit GN (2006) Soil seed bank characteristics in relation to land use systems and distance from water in a semi-arid rangeland of southern Ethiopia. South Afr J Bot 72:263-271

Solomon T, Snyman HA, Smit GN (2007) Cattle-rangeland management practices and perceptions of pastoralists towards rangeland degradation in the Borana zone of southern Ethiopia. J Environ Manag 82:481-494

t'Mannetje L, Jones RM (2000) Field and laboratory methods for grassland and animal production research. CABI, Wallingford

Tainton NM (1981) The ecology of the main rangelands of South Africa. In: Tainton NM (ed) Veld pastures management in South Africa. Shuter and Shooter, Pietermaritzburg

Teame G, Tessema Z, Emiru B (2014) Effect of human settlement and altitude on rangeland herbaceous species biodiversity and productivity in Kafta-Humera Woreda, Tigray, Ethiopia. J Environ Earth Sci 4:108-113

Teem DH, Hoveland CS, Buchanan GA (1980) Sicklepod (Cassia obtusifolia) and coffee senna (Cassia occidentalis); geographic distribution, germination and emergence. Weed Sci 28:68-71

Tessema ZK, de Boer WF, Baars RM, Prins HH (2011) Changes in soil nutrients, vegetation structure and herbaceous biomass in response to grazing in a semi-arid savanna of Ethiopia. J Arid Environ 75:662-670

Tessema ZK, de Boer WF, Baars RM, Prins HH (2012) Influence of grazing on soil seed banks determines the restoration potential of aboveground vegetation in a semi-arid savanna of Ethiopia. Biotropica 44:211-219 
Tungate KD, Susko DJ, Rufty TW (2002) Reproduction and offspring competitiveness of Senna obtusifolia are influenced by nutrient availability. New Phytol 154:661-669

Tye A, Soria MC, Gardener MR (2003) A strategy for Galapagos weeds. In: Veitch CR, Clout MN (eds) Turning the tide: the eradication of invasive species. Proceedings of the international conference on eradication of island invasive. IUCN, Gland, pp 336-341

Van Reeuwijk LP (1992) Procedures for soil analysis, 3rd edn. International Soil Reference Centre Wageningen (ISRIC), Wageningen

Veenendaal EM, Ernst WHO, Modise GS (1996) Reproductive effort and phenology of seed production of savanna grasses with different growth form and life history. Vegetatio 123:91-100

Walkley A, Black CA (1934) An examination of wet digestion method for determining soil organic matter and proposed modification of the chronic acid titration method. Soil Sci 37:29-38

Wardle DA, Bardgett RD, Callaway RM, Van der Putten WH (2011) Terrestrial ecosystem responses to species gains and losses. Science 332:1273-1277

Waterhouse DF, Norris KR (1987) Cassia tora and C. obtusifolia. In: Biological control. Pacific prospects. Inkata, Melbourne, pp 288-295

Weber E (2003) Invasive plant species of the world: a reference guide to environmental weeds. CABI, Wallingford

Zimmermann J, Higgins SI, Grimm V, Hoffmann J, Linstader A (2010) Grass rate of change in semi-arid savanna: The role of fire, competition and self-shading. Perspect Plant Ecol Evol Syst 12:1-8

ZOIC (Western Zone Office of Information and Communication) (2015) Hiza'eti Tigray, vol 3. Western Zone Office of Information and Communication, p 36

\section{Submit your manuscript to a SpringerOpen ${ }^{\circ}$ journal and benefit from:}

- Convenient online submission

- Rigorous peer review

- Open access: articles freely available online

- High visibility within the field

- Retaining the copyright to your article

Submit your next manuscript at $\boldsymbol{s p r i n g e r o p e n . c o m ~}$ 